\title{
Research on Securities Trader M\&A Business Profit Model in China
}

\author{
Tan Qiuheng \\ Guosen Securities Co., Ltd. \\ Shenzhen, China \\ tanqiuheng5588@sina.com
}

\begin{abstract}
M\&A business is developed in global M\&A trend. M\&A business is one of core businesses for investment banks in western countries. In recent years, foreign securities trader M\&A business is rapidly developed, which has become one of the businesses with the fastest growth speed. M\&A business has become supplement of foreign securities traders to traditional business, which brings huge profit to foreign securities traders. Business profit model of foreign securities traders is changed. Currently, Chinese securities traders are mainly based on stock issuance and consignment sales. M\&A business development is still in the starting stage, M\&A business has low development level, thereby making less contribution to overall profit of securities traders. Therefore, securities trader M\&A business profit model in China is studied. Development status of securities trader M\&A business and M\&A business profit model in China are analyzed. Countermeasures to promote securities trader M\&A business development in China are proposed. In the paper, it is believed that China securities trader M\&A business should be developed from the following four aspects: improving relevant laws and regulations of M\&A business; adjusting business structure and strengthening M\&A business innovation; accelerating development of M\&A fund; improving professional talent quality of M\&A business. Therefore, profit model of securities trader M\&A business can be enriched.
\end{abstract}

\section{Keywords-securities trader; M\&A business; profit model}

\section{CURRENT SITUATION OF SECURITIES TRADER M\&A BUSINESS IN CHINA}

Fig. 1 shows transaction scale of Chinese M\&A market from 2011 to 2014. It is indicated in the figure that China M\&A market is developed very fast. Transaction scale of China M\&A market was $\$ 66.918$ billion in 2011, which was $\$ 50.762$ billion in 2012, $\$ 93.203$ billion in 2013, and $\$ 118.49$ billion in 2014. We can observe that M\&A market is developed well in China, ad a great opportunity is provided for securities traders to improve profit structure and strengthen M\&A business development. Currently, China economy is in the crucial stage of structural adjustment. Enterprise restructuring and industry consolidation provide wide development market for securities trader M\&A business. M\&A among enterprises will be more and more with deepening of economic reforms and increasingly fierce competition. In addition, acquisition and reorganization examination and approval policies are loosened in China, M\&A market is more and more active, thereby providing better development prospect for M\&A business in China.
2011-2014 China M \& A Transaction Amount (Million Dollars)

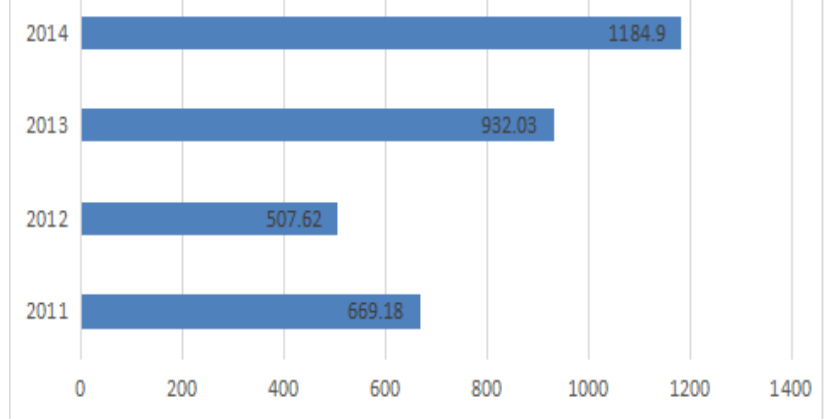

Figure 1. Transaction scale of Chinese M\&A market from 2011 to 2014

Currently, securities trader M\&A business is not developed to a very mature stage, which is characterized mainly in the following three aspects:

\section{A. M\&A business is concentrated in a few securities traders.}

M\&A business accounts for low proportion in total income of securities traders. Currently, main business of securities traders includes brokerage business and security consignment recommendation. Other business development is relatively less. M\&A business makes less contribution of overall profit of securities traders. Most M\&A businesses are included in securities trader investment department, which are not separated, thereby hindering development of M\&A business in organization.

\section{B. Securities trader is characterized by insufficient $M \& A$ experience, narrow service space and low consulting service quality.}

Investment banks in west countries can complete planning in all links of enterprise M\&A activities. They can provide one-stop services from the consultation before M\&A to services after M\&A. However, forces of investment bank are faded to certain extent in China due to intervention of the government department, thereby losing main technical foundation as financial consultants. Investment banks play limited role in enterprise M\&A. In addition, more and more financial institutions participate in enterprise M\&A business currently, thereby leading to phenomenon that there is too little meat for so many wolves. In addition, many financial institutions are not investment banks in the true sense, which are lack of M\&A 
experience. Their consulting service quality is not high, and they can not play own role in M\&A. Chinese securities traders can not provide systematic services for enterprises due to own strength and insufficient experience. Though M\&A trading department has been established by some securities traders, the service quality still should be improved.

\section{Income of securities trader M\&A consultants is increased, but the market scale is small.}

Securities trader M\&A financial consultants are continuously updated in China M\&A market. Income of securities trader M\&A consultants is also gradually increased with increase of transaction scale in China M\&A market, and it gradually improves the contribution proportion to securities trader profit. Table 1 reflects M\&A business income condition of Chinese securities traders and investment banks from 2011 to 2014. It is obvious in the table that income of securities trader M\&A consultants is increased year by year in China, the growth rate is faster, income of securities trader M\&A consultants was 1.249 billion Yuan in 2011, which was up to 6.919 billion Yuan in 2014. The proportion of M\&A income in business revenue shows that the proportion of securities trader M\&A income in business revenue can maintain stable under the condition rapid increase of business revenue. In summary, the proportion is very low. Proportion of M\&A consultant income in investment bank income shows that M\&A consultant income is increased in investment bank income. However, the proportion is not so good. Table 1 shows that value of financial consultant in M\&A value is not fully recognized with lower development degree.

TABLE I. M\&A BUSINESS INCOME CONDITION OF CHINA SECURITIES TRADER AND INVESTMENT BANK FROM 2011 TO 2014

\begin{tabular}{|c|c|c|c|c|c|}
\hline Year & $\begin{array}{c}\text { M\&A } \\
\text { consultan } \\
\text { tincome } \\
\text { (hundred } \\
\text { million } \\
\text { Yuan) }\end{array}$ & $\begin{array}{c}\text { Business } \\
\text { revenue } \\
\text { (hundred } \\
\text { million } \\
\text { Yuan) }\end{array}$ & $\begin{array}{c}\text { M\&A } \\
\text { consultant } \\
\text { income } \\
\text { /Business } \\
\text { revenue }\end{array}$ & $\begin{array}{c}\text { Investme } \\
\text { nt bank } \\
\text { business } \\
\text { income } \\
\text { (hundred } \\
\text { million } \\
\text { Yuan) }\end{array}$ & $\begin{array}{c}\text { M\&A } \\
\text { consultan } \\
\text { t } \\
\text { income/In } \\
\text { vestment } \\
\text { bank } \\
\text { income }\end{array}$ \\
\hline 2011 & 12.49 & 1359.5 & $0.92 \%$ & 241.38 & $5.17 \%$ \\
\hline 2012 & 35.51 & 1294.71 & $2.74 \%$ & 212.95 & $16.68 \%$ \\
\hline 2013 & 44.75 & 1592.14 & $2.81 \%$ & 173.37 & $25.81 \%$ \\
\hline 2014 & 69.19 & 2602.84 & $2.66 \%$ & 240.19 & $28.81 \%$ \\
\hline
\end{tabular}

\section{ANALYSIS ON SECURITIES TRADER M\&A BUSINESS PROFIT MODEL}

\section{A. Financial consultant income}

There is no a relatively uniform standard for charging securities trader M\&A financial consultant fees. M\&A financial consultant income is different due to difference in M\&A operation complexity, operating cycle, M\&A target and other aspects. In general, M\&A consultant fee of listed companies is higher than M\&A fee of unlisted companies. M\&A fee of listed companies involving state equity is higher than the M\&A fee of listed companies of legal person shares. Financial consultant fees are determined in one time after negotiation between financial consultant of securities trader and client. The M\&A financial charges are greatly different from that in western countries. Fixed cost and cost based on transaction price change are mainly retained in consultant fee of investment bank M\&A business in western countries, concretely including hiring deposit, consulting fee, sales representative fee, transaction management fee, suspension fee, impartial advice fee, contingent fee, etc. Clients are more and more dependent on the securities trader financial consultant with deepening of China M\&A complexity. Clients pay more and more consultation fees to consultants. Securities trader M\&A financial stake business and traditional investment banking business have different advantages and disadvantages. Project cost of traditional investment bank is higher, which can be up to more than 10 million generally. After the transaction is completed, the income can be greatly guaranteed. Securities trader M\&A financial consultant business has shorter M\&A operation cycle compared with investment bank, and the operation quantity is not limited. There is basically no business risk, and corporate resources are not occupied. In addition, Value content recognition of financial consultant service in market M\&A is increased, and profit prospect of M\&A business is more optimistic with the expanding of domestic M\&A market and rising of M\&A complexity. Industry average yield is decreased. Per capita profit advantages and growth potential of M\&A business are more prominent under the condition aiming at securities traders.

\section{B. Related business development}

Many securities traders adopt comprehensive development approach in China. Service keys of securities traders are changed from the original focus on project to client orientation. The service mode is changed from previous single service to current supply of solution. Solution provided by securities traders to clients refers that securities traders design financial tools required by the client according to actual condition of the client. Strategic management consultant services, bond consignment services, private placement consultancy services, equity consignment services, asset restructuring consultant services, M\&A consultant services, investment consultant services and services in other aspects are provided for clients. Security traders not only can obtain financial consultant fees, but also can achieve profits of M\&A business related development business through providing the clients with M\&A business under the background. Securities trader provides clients with M\&A business, and establishes good relationship with clients through developing professional business, thereby securities traders can develop business related to financial consultant. These related businesses can be regarded as one of securities trader M\&A business incomes.

\section{Other profit model}

Investment banks M\&A business profit models in Western countries are far more than financial consultant business and related business profit mode. Foreign investment bank giant M\&A business profit models also include M\&A investment business and M\&A financing business. M\&A investment business is one of important businesses of investment banks in western countries. Morgan Stanley and Goldman Sachs purchase nonperforming assets in China. Greater profits can be obtained by making use of their advantages in management, 
technology and experience for handling non-performing assets. M\&A financing service refers that investment banks provides bridge loan for acquirer. Currently, there are many problems in China financial market currently. However, the market is gradually improved. China securities trader M\&A business profit model will be more and more diversified with national adjustment in China, and more profits can be obtained

\section{COUNTERMEASURES TO PROMOTE DEVELOPMENT OF SECURITIES TRADER M\&A BUSINESS}

\section{A. Improving relevant laws and regulations on $M \& A$ business}

Securities traders should take advantage of the existing laws and regulations in China for actively exploring M\&A business. They should constantly innovate and explore more M\&A business profit models according to actual circumstance of financial market in China by drawing lessons from foreign experience in investment banking. In addition, China should improve related laws and regulations of $M \& A$ business, standardize $M \& A$ market, make clear securities trader setup procedure, setup standard, basic business rules, business scope, regulatory management, legal liability, etc., revise and supplement aspects in existing laws and regulations which are unfavorable for securities traders to develop M\&A business. Laws in the aspects of enterprise antitrust and enterprise M\&A should be established and perfected, thereby ensuring the enterprise M\&A process can be smoothly implemented under law system. China law formulation department should establish a set of scientific and perfect securities trader M\&A law system according to experience and practice of securities trader in enterprise M\&A business. Detailed rules of securities trader M\&A business are made clear. Securities trader M\&A bottlenecks can be changed, securities trader financing problems can be improved, thereby providing good legal environment for developing securities trader M\&A business in China.

\section{B. Adjusting business structure and strengthening innovation of M\&A business}

Securities trader in China should constantly improve own competitiveness, adjust business structure, and strengthen innovation of M\&A business. Securities company can consider expanding capital scale through increase in capital and share, merger, acquisition and reorganization, etc., thereby improving competitiveness and management level of securities company. They should actively expand business, especially M\&A business, change traditional management ideas, and mainly break through M\&A business. Sound economic trend in current stage should be fully utilized for increasing income of M\&A business. Securities companies should strengthen innovation of M\&A financial consultant and M\&A planning business. Securities company can provide consultant, innovation planning and financing services for M\&A transaction as an intermediary, thereby forming unique business direction, or it can regard friendly $M \& A$ and anti-hostile M\&A as features, or treat cross-border M\&A business as important breakthrough points; In addition, property investment business should be realized, securities company also can act as subject of M\&A business, property right sales should be regarded as an innovation investment business, thereby realizing income between sales and purchase price different, and enriching profit models of securities trader M\&A business.

\section{Accelerating development of $M \& A$ fund}

M\&A fund refers to the fund focused on engaging in enterprise M\&A investment. After equity of target enterprise is obtained by the mode of holding or joint stock, a series of business restructuring reformation and management integration are implemented on the target enterprise. After its profit is increased, the equity can be sold. In general, M\&A fund comes from own fund of the security company and fund raised in concealed form. However, fund problem in M\&A is solved through M\&A fund at international level at present. Chinese securities traders can set up M\&A fund through establishing direct branch company, M\&A fund is beneficial for introducing professional team and promoting M\&A business development on one hand. Investment value can be discovered in the investment process by M\&A fund, and bridge support can be provided for M\&A client on the other hand. After the equity of the acquired party is obtained, exit of investment can be realized through equity transfer, thereby benefiting all parties.

\section{Improving professional talent quality of $M \& A$ business}

Talents play an important role in enterprise development. Talent quality determines competitiveness of an enterprise. M\&A not only requires acquisition and analysis of information, but also needs creativity and ideas at high degree. Combined resource implementation plan also should be formulated. Professional talents with higher quality are required for completing composite M\&A business. Currently, China M\&A market is mainly composed of consignment and distribution personnel. These personnel can not meet talent requirement of securities M\&A business in the aspects of operation, professional knowledge and thinking mode, thereby seriously affecting development of securities trader M\&A business. Therefore, securities companies should strengthen the cultivation of M\&A professional talents, improve their M\&A business professional level, strengthen the communication and learning with foreign investment bank, intensify staff technology training, introduce advanced management experience and technology, actively introduce and cultivate senior professional talents of securities companies in M\&A business, establish performance evaluation mechanism, drive competition among M\&A talents of securities companies, and stimulate creativity and enthusiasm of staff, thereby improving talent quality of the securities company in M\&A business, and enriching M\&A business profit models in securities traders.

\section{CONCLUSIONS}

Currently, China securities trader business is characterized by single structure and low profit. Brokerage business supply exceeds demand, which suffers from huge competition pressure. Industry commission is declined as a whole. Sudden huge profit period of securities trader brokerage business is over. The securities traders should 
seek new profit models under the background. M\&A business is well development in foreign market. It has greater development prospect in China. Therefore, M\&A business profit model of securities traders is analyzed in the paper. It is discovered that M\&A business profit models of securities traders in China mainly include financial consultant income, related business development and other profit model. I believe that laws and regulations about M\&A business should be perfected, business structure should be adjusted, M\&A business innovation should be strengthened, development of M\&A fund should be accelerated, and M\&A professional talent quality should be improved in order to promote development of securities trader M\&A business in China.

\section{REFERENCES}

[1] Qing Song, Wang Cunfu. "Status quo and countermeasures of profit model for China securities companies-analysis based on business structure," Zhejiang Finance, 2010 , vol. 2, pp. 69-70

[2] Xu Jiana. "Discussion of securities company profit model transformation from the perspectives of the balanced development," Journal of Beijing University of Posts and Telecommunications (social science edition), 2010, vol. 2, pp. 124-125.
[3] Han Yiqing, Chen Xiaoqian, Pan Xiaosu. "Comparative analysis on profit models of China securities companies," Oriental Enterprise Culture, 2012, vol. 16, pp. 77-78.

[4] Zhang Xiangdong. "Comparison and reference of asset securitization regulatory models in China and America," Shanghai Finance, 2012, vol. 8, pp. 35-36.

[5] Mou Huiping. "Development of M\&A business and improvement of business competitiveness of securities trader investment bank," Commercial Forum, 2007, vol. 8, pp. 89-91.

[6] Deng Longna. "Thinking on M\&A business development in China securities traders," Guangxi Financial Research, 2005, vol. 10, pp. 115-116.

[7] Shao Xia. "On profit model transformation and innovation of securities company," Cooperation Economy and Technology, 2010, vol. 13, pp. 38-40.

[8] Tian Manwen, Yan Shurong. "Government Intervention, Agency Costs and Efficiency of Merger and Acquisition Integration an Empirical Analysis of Chinese Listed Companies," International Conference on Financial Risk and Corporate Finance Management, 2013, pp. 291-298.

[9] Le Qi. "Executive Changes, Legitimacy and M \& A Performance after the Merger," Journal of Industrial Engineering and Engineering Management, 2012, vol. 3, pp. 15-21

[10] Qi Jipeng, Wang Siwen. "Analysis of Factors Affecting the Performance of M \& A of Listing Corporation," Research on Financial and Economic Issues, 2012, vol. 9, pp. 81-86. 